\title{
Efficiency of Working Capital Management and Profitability: Evidence from Manufacturing Firms of Nepal
}

Pitambar Lamichhane*

\begin{abstract}
This paper analyzes efficiency of working capital management (EWCM) and its influence on profitability of manufacturing firms in Nepal for the fiscal year 2005/06 to 2017/18 using descriptive and causal comparative research design. Net trade cycle (NTC) is used to measure EWCM. Profitability on assets (PA) and profitability on sales (PS) are dependent variables of this study. The EWCM related variables such as Net trading cycle (NTC), current ratio (CR) and debt to assets ratio (DR) are considered as explanatory variables. Result of this paper reveals both profitability on assets and profitability on sales are inversely related with NTC which implies that lower NTC increases profitability of manufacturing firms in Nepal. Further, regression result of this paper confirms that debt to assets ratio has negative and statistically significant effect on profitability on total assets and profitability on sales. The finding of this paper concludes that less uses of debt increases the profitability of manufacturing firms in Nepal.
\end{abstract}

Key words: Working capital management, efficiency, net trade cycle, current ratio, debt ratio, profitability on assets, profitability on sales.

\section{Introduction}

Working capital is essential for day to day smooth operation of business activities. It is capital for managing short-term assets such as cash, inventories, receivables, marketable securities etc. Net working capital of a firm is the excess of short-term assets over current liabilities of a firm. It is long-term sources of financing for managing short-term assets. Working capital is a financial yard-stick which shows liquidity of a business firm and it depicts short-term financial health of the firm.

Decision process for managing short-term assets is defined as working capital management (WCM). WCM is concerned with decisions regarding to short-term assets and liabilities of a business firm. In another word, it is the process of managing cash, inventories, accounts receivable, and accounts payable. Van Horne (1977) stated WCM as the process of managing of short-term assets such as cash, saleable securities, inventories, receivables etc. WCM plays a vital role in a firm to maximize profitability and minimize risk and consequently increases

* Mr. Lamichhane is Associate Professor at Tribhuvan University, Faculty of Management, Shanker Dev Campus

Email: lamichhanepr47@gmail.com 
firm's value (Smith, 1980). Fundamental principles of WCM are to minimize in capital employed and to improve efficiency in use of cash, inventories, receivables, and payables. Firms can reduce risk by careful management of working capital. The sound WCM has imperative role in maintaining optimum size of cash, inventory, receivables, and payables for regular operation of various business activities. The optimization of working capital minimizes working capital financing requirement and maximizes revenues and wealth of the firm. Smith (1973) observed that the most of business firms are failure due to lacking of ability of financial managers in sound financial planning and controlling of current assets and liabilities. The efficient management of working capital has crucial role for small business firms for their survival and development (Grablowsky, 1984).

WCM is a yardstick to measure firm's operational as well as financial efficiency. Sound and efficient working capital management (EWCM) system increases earnings of a business firm. Management of a firm should prepare strategic and operational plans and efforts should continuously be given to improve its working capital position. The sound WCM yields greater efficiencies of the firm which leads to improve customer satisfaction. The issue about why WCM is significant for a firm is to focus on the relationship between efficiency of WCM and firm's profitability. The efficient WCM includes planning, managing and controlling of shortterm assets and liabilities to avoid unnecessary extreme investments of financial resources in current assets to minimize costs and maximize value of shareholders' wealth.

Cash conversion cycle of a firm is usually used to measure the efficiency of WCM. It is the length of time period during which money is transferred to goods and services and again to money. It is time gap between spending for purchases of raw materials and cash collection from sales of finished products. The longer cash conversion cycle (CCC) requires larger size of investment in working capital. A longer CCC increases sales and leads to increase profitability of the firm. However, firm's profitability may decreases with increase in CCC if cost of working capital is higher than benefits with holding more inventories and giving more credit facilities to customers because of more investment in working capital. Deloof (2003) argued that longer CCC of a firm extends more financing of working capital. In one aspect, extension of CCC can increase sales and results to increase firm's profitability. But, in another aspect, extension of CCC needs more working capital financing in parallel and brings an additional financing cost and reduces profitability of the firm.

The previous theoretical as well as empirical studies show that WCM efficiency is an essential part of corporate strategy to maximize shareholders' value in a firm. The efficient WCM has a significant impact on liquidity and profitability of the firm. WCM decisions tend to maximize profitability but may not to maximize liquidity position of the firm. Equally, focusing entirely on liquidity tends to reduce potential profitability of the firm. The efficient WCM affects profitability of the firm, its risk, and value (Smith, 1980).

The efficient WCM is an important component of general strategy for increasing market value of a business firm (Deloof, 2003; Afze \& Nazir, 2007). Filbeck and Krueger (2005) stated 
that success of a firm depends on ability of financial manager to make efficient management of cash, inventories, receivables, and liabilities. In the empirical studies made by Shin and Soenen (1998), Deloof (2003), Raheman and Nasr (2007) and Teruel and Solano (2007) revealed a negative association between CCC and profitability of the corporation. The major elements of CCC such as cash, inventories, account receivables and short-term trade liabilities should properly be managed through more efficient WCM to maximize profitability of the firm.

Al-Mwalla (2012) examined impact of WCM policies on profitability and value of the firm and revealed a negative and significant relationship between aggressive working capital policy and profitability showing excessive reliance on short-term debt may lead to liquidity problems. There is a negative association between efficiency of WCM and profitability in US hospitals (Rauscher \& Wheeler, 2012). Kaur and Singh (2013) stated that WCM involves firm's cash, receivables, inventories, payables etc. in a way which leads to maximize firms' profitability.

In the study of corporate governance and WCM efficiency of American manufacturing firms, Gill and Biger (2013) revealed a significant positive association between WCM efficiency and profitability of US manufacturing firms. Kroes and Manikas (2014) analyzed cash flow management and financial performance of manufacturing firms and argued a nonsignificant relationship between WCM and financial performance of US manufacturing firms. Wasiuzzaman (2015) studied on working capital practices of Malaysian companies using ordinary least square regression approach and revealed that efficiency of WCM significantly leads to increase values for the financially constrained firms rather than financially nonconstrained firms.

Panigrahi (2017) analyzed the relationship between WCME and profitability of Indian cement industry by applying descriptive and regression research design for the period 20062015. The results of the study reveal the negative relationship of inventory conversion period and payable deferral period with profitability and positive relationship between receivable conversion period and profitability of the firms. The finding of the study concludes that cash conversion cycle as efficiency of WCM adversely affects the profitability of firms.

In the study of WCM and profitability, Paul and Mitra (2018) examined the impact of WCM on profitability by using regression models for the study period 2000-2016. The study has considered profitability as dependent variables whereas quick ratio, current ratio, inventory turnover and debt ratio as explanatory variables. The finding of the study concludes that WCM has significant impact on profitability of the firms.

Vartak and Hotchandani (2019) analyzed WCM and performance of Indian firms by applying correlation and regression models for the study period of 2009-2018 and revealed that WCM has inverse but significant relation with financial performance of the firms. Result of the study indicates significant impact of inventory turnover and CCC on financial performance whereas 
insignificant impact of accounts payables. The finding of study concludes that efficient WCM increases the financial performance of Indian firms.

In the study of working capital management, Emery (1984) argued trade credit is an incentive for customers to obtain products at periods of low demand which is agreed to ensure that services based on contract carried out. Smith (1980) revealed 20 percent firms that invest heavily in inventory and trade credit can suffer and reduce their profitability. In addition, larger investment in inventories reduces stock-out problems and increases profitability. The suppliers of products may have more cost advantages than financial institutions by providing credit facility to its buyers which can be less expensive source of financing for the customers (Petersen \& Rajan, 1997).

Trade credit facility may reduce price effectively. Granting of credit may favor to increase sales of firms in different ways. In one hand, postponement of payment to suppliers permits firms to measure quality of products and it can be less expensive as well as flexible sources of short-term financing. In other hand, late payment to suppliers may be more costly if discount is offered by the firm for its early payments. The major theories of WCM are related with profitability and liquidity of the firm (Beaumont \& Begemann, 1997). Further, authors argued that existence of trade-off between liquidity and profitability of a firm is essential. The connection of working capital and profitability helps to understand the association between liquidity and profitability of the firm.

WCM of a firm should focus to trade-off liquidity and profitability for smooth operation of day to day business activities. Deloof (2003) revealed that sound working capital management has impact on profitability and liquidity of firms. This result implies that there should be an optimum size of working capital requirements which helps to maximize returns of the firm. Lazaridis and Tryfonidis (2005) argued that the most of small firms focus on management of inventory where as low profitability firms focus on credit management.

Padaehi (2006) argued that the WCM is important to make financial health for all sizes of businesses firms. This importance is centered on two reasons: (a) amount invested in working capital is often high in proportion to total assets and it is essential to be used in efficient way, (b) management of working capital directly affects firm's profitability and liquidity and consequently effects on its net worth. Ganesan (2007) suggested that less competitive firms should focus to reduce cash conversion cycle for minimizing account receivables, while more competitive firms should increase cash conversion cycle to have a comparatively higher level of account receivables.

The previous empirical studies in financial literature show that efficiency of WCM increases free cash flow and increases growth opportunities of firms which lead to maximize shareholders' values and returns of firms. Even though firms traditionally are focused on long-term investment and financing, but, recent trend shows that many firms are focusing to increase efficiency on working capital management. Results of empirical analysis of prior 
studies show that there is statistical evidence of strong association between WCM efficiency and firm's profitability. The preponderance of the prior empirical studies on WCM efficiency and profitability of firms carried out in the developed and developing countries but a very few studies have been administered in developing countries and there is lacking in-depth studies in under-developing countries like Nepal. Thus, this study is an attempt to analyze the relationship between efficiency of WCM and profitability of manufacturing firms in Nepal.

\section{Objective of the Study}

The basic objective of this study is to analyze the relationship between efficiency of working capital management and profitability of manufacturing firms in Nepal.

This paper is structured into five sections. The section one deals with introduction of the study along with objective of this study. The next section two briefly summarizes with measures of WCM efficiency. Section three covers research methodology. Section four of this paper deals with data analysis and results. Finally, section five summarizes the conclusion of the study.

\section{Measures of Working Capital Management Efficiency}

Financial manager's key role is in generation of cash flows and to use them for generating profit of a firm. Cash flows are life blood of business firms. If firms are able to generate more cash inflows are able to make more profits. If firms have more cash inflows and profits they can easily survive in the market, if not, firms may be in financial distress and become bankruptcy and ultimately they will be liquidated. Thus, sound working capital management decision of a firm generates more cash inflows and helps to increase profitability and reduces risk of firms. The requirements of working capital of firms are determined based on cash conversion cycle (CCC). The CCC shows the efficiency of WCM of the firm.

Cash conversion cycle is time difference between cash payments for raw materials and collection for sales. It refers time span between cash collection and cash disbursement of a firm. Firm's CCC focuses on time between cash payments made to suppliers for materials and wages to labor and payments received from sales to customers. It is difference between operating cycle and payment periods. It is determined as sum of length of holding period of inventory (inventory conversion period) plus average collection period (receivable conversion period) minus average payable period (payable deferral period). Inventory conversion period is calculated as days in a year divided by inventory turnover, receivable conversion period is determined as days in a year divided by receivable turnover and payable deferral period is computed by days in a year divided by payable turnover. In the study of estimating corporate liquidity requirements, Gitman (1994) introduced CCC concept as a crucial component in WCM to measure efficiency of working capital management of firms.

Working capital requirement of a firm depends on its length of cash conversion cycle. A firm can make more sales adopting a liberal credit policy which extends receivable conversion period as well as cash conversion cycle. Lengthy CCC results higher profitability through higher level of sales. However, traditional theory on the relationship between CCC and firm's 
profitability argued that a longer CCC hurts profitability of firm because of more cost of investment in receivables. Relaxed credit policy requires more investment in working capital. Purchase on trade credit reduces in working capital requirements because account payables are used as short-term sources of financing of firms.

Requirement of working capital, sales and profitability are directly affected by size of inventories and receivables of a firm. Both larger inventory and liberal credit policy require more working capital financing and may lead higher sales which results higher profitability of the firm. Working capital management decision relating its major components such as inventory, receivables and payables affects length of cash conversion cycle, working capital requirement, level of sales and profitability. Thus, efficiency of WCM of a firm is determined based on cash conversion cycle.

The weighted average cash conversion cycle (WACC) and net trade cycles (NTC) are two major concepts of cash conversion cycles commonly used for measuring WCM efficiency. The concept of WACC was developed by Gentry, Vaidyanathan and Lee (1990). The weights are determined by dividing amount of each tied up in each item by final value of the item. WACC considers both number of periods in days and tied amount of funds at each step of cash conversion cycle. Another key measure of WCM efficiency is net trade cycle (NTC) of firms. It is equal to the CCC where all components inventory, receivables and payables are expressed as percentage of sales. NTC indicates number of days sales of a firm which needs to finance its working capital. Net trade cycle is commonly used to make an easy estimation in determining additional financing needs for working capital requirements to meet projected sales of the firm.

In this paper, length of firm's NTC is considered as a measure of efficiency of WCM. NTC closely relates with issue of shareholders' value creation in the firm. Shorter NTC results higher net present value of cash flows generated by assets and thus, leads higher value of firm for its shareholders. Likewise, shorter NTC represents more efficient in managing working capital of the firm which lowers need of external financing and it results higher financing performance. Thus, inverse relationship between firm's NTC and its profitability is expected.

\section{Research Methodology \\ Research Design}

This paper has applied descriptive and causal comparative research design to analyze the relationship between efficiency of WCM and profitability of manufacturing firms in Nepal. This study attempts to describe the impact of WCM efficiency (net trade cycle, current assets to liabilities ratio and debt to assets ratio) on firm's profitability (return on assets and sales). In this paper, correlation analysis has been used to establish the magnitude and direction of relationship between efficiency of working capital management and profitability of manufacturing firms in Nepal. Moreover, this study has adopted regression analysis to 
determine the effect of net trade cycle (NTC), current ratio (CR), and debt to assets ratio (DR) on profitability on assets (PA) and profitability on sales (PS).

This paper has used Pearson correlation analysis to observe the association between efficiency of working capital management and firm's profitability. Furthermore, this study has employed cross sectional regression models to test the effects of efficiency of working capital on profitability of manufacturing companies in Nepal. The ordinary least square (OLS) regression model has been used to estimate regression line to examine the effect of WCM efficiency on firm's profitability to analyze their relationship. The OLS approach is applied to minimize errors between estimated points and actual observed points of the estimated regression lines.

\section{Nature and Sources of Data}

This paper has used secondary sources of data. For secondary data set, necessary information is collected from periodical reports and statements published by Security Board of Nepal (SEBON), and financial statements of respective sample firms covering the period of thirteen years from fiscal year 2005/06-2017/18.

\section{Population and Sample}

In this paper, total 196 companies listed in the NEPSE till Mid-July 2018 are considered as population. Out of total population by the end of fiscal year 2017/2018, 13 firms out of 18 listed manufacturing companies are selected as sample. Total 160 observations are used to analyze relationship between efficiency of WCM and profitability of manufacturing firms in Nepal. The data of this study has been collected from Annual Report of SEBON and financial statement of respective sample firms.

\section{Analytical Tools}

The collected data of this paper has been processed and analyzed based on software SPSS (version 20), and MS-Excel. In this paper, correlation analysis, regression analysis along with t-test, F-test, Adjusted $\mathrm{R}^{2}$, Durbin-Watson (DW) statistics and Variance Inflationary Factor (VIF) have been used to analyze data for examining the relationship between efficiency of WCM and profitability of manufacturing firms in Nepal.

\section{Variables}

In this paper, profitability on assets (PA) and profitability on sales (PS) are considered as dependent variables. The PA is computed as percentage of sum of net operating income and depreciation on total assets. The PS is determined as percentage of sum of net operating income and depreciation on total sales. The prior theoretical as well as empirical studies have observed several factors that affect firm's profitability. In this paper, net trade credit (NTC), current to liabilities ratio (CR) and total debt to assets ratio (DR) are considered as explanatory variables. The variables used as efficiency of working capital management and profitability of this paper are computed as follows: 
In this paper, efficiency of WCM is measured by net trade cycle and it is calculated using equation 1.

NTC $=\frac{(\text { Inventory }+ \text { Accounts Receivable }- \text { Accounts Payable }) \times 365}{\text { Sales }} \quad \ldots$

In this paper, firm's profitability on total assets and profitability on sales are calculated using equation 2 and equation 3 respectively.

$\begin{array}{ll}\text { Profitability on Assets } & (P A)=\frac{(\text { NOI }+ \text { Depreciation })}{\text { Totäl Assets }} \\ \text { Profitability on Sales } & (P S)=\frac{(\text { NOI + Depreciation })}{\text { Net Sales }}{ }^{\cdots}\end{array}$

NOI refers net operating income of sample firms.

In this paper, current ratio and debt ratio are estimated to show the association between current ratio and profitability as well as between debt ratio and profitability using equation 4 and equation 5 respectively.

Current Ratio $(\mathrm{CR})=\frac{\text { Total Current Assets }}{\text { Total Current Liabilities }}$

Debt Ratio $(\mathrm{Dr})=\frac{\text { TotalDebt }}{\text { Total Assets }}$

\section{Model Specification}

The multiple regression models of equations 6 and 7 are used to analyze the influences of explanatory variables on profitability of manufacturing firms in Nepal.

Profitability on Assets $(P A)=a_{0}+\beta_{1} N T C+\beta_{2} C R+\beta_{3} D R+\varepsilon_{t}$

$\ldots$

Profitability on Sales $(P S)=a_{0}+\beta_{1} N T C+\beta_{2} C R+\beta_{3} D R+\varepsilon_{t}$

NTC is net trade cycle, CR represents current ratio, DR indicates debt ratio, $a_{0}$ is the coefficient of constant or intercept term, $\beta_{1} \beta_{2} \& \beta_{3}$, are coefficient of explanatory variables, and $\varepsilon_{\mathrm{t}}$ is error term.

\section{Data Analysis and Results}

This section of paper attempts to analyze data associated with efficiency of WCM and its factors affecting firm's profitability. This paper deals with working capital management efficiency, current ratio, debt ratio and their effect on firm's profitability to observe and analyze the relationship among these variables. Correlation and regression analysis under causal comparative research design have been applied to analyze and explore the relationship between efficiency of working capital management and corporate profitability in Nepalese manufacturing firms. 


\section{Correlation Analysis}

This paper has used net trade cycle, current ratio and debt ratio as explanatory variables to analyze profitability of manufacturing firms in Nepal. In this study, Pearson's correlation coefficient is used to measure the linear association for explaining the direction and magnitude of relationship among net trade cycle (NTC), current ratio (CR), debt ratio (DR) and firm's profitability i.e. profitability on assets(PA) and profitability on sales (PS). Table 1 presents correlation coefficient of variables to explain relationship between firm's profitability and its explanatory variables during the study period.

Table 1: Correlation Coefficients of Corporate Profitability and Explanatory Variables

\begin{tabular}{|l|c|c|c|c|c|}
\hline \multicolumn{1}{|c|}{ Variables } & PA & PS & NTC & CR & DR \\
\hline PA & 1 & $0.849^{* *}$ & $-0.241^{*}$ & $0.284^{*}$ & $-0.658^{* *}$ \\
\hline PS & - & 1 & $-0.126^{*}$ & $0.397^{*}$ & $-0.439^{* *}$ \\
\hline NTC & - & - & 1 & $0.218^{*}$ & -0.216 \\
\hline CR & - & - & - & 1 & -0.315 \\
\hline DR & - & - & - & - & 1 \\
\hline
\end{tabular}

Source: SEBON (2005/06-2017/18).

Note: ' '*' indicates that correlation is significant at 5 percent level, '**' indicates that correlation is significant at 1 percent level.

Table 1 shows value of Pearson's correlation coefficient between different pairs of explanatory variables and firm's profitability. The result has exhibited in Table 1 indicates profitability on assets (PA) and profitability on sales (PS) and both are positively related with current ratio of the firms but relationship is not strong. The PA and PS both are negatively correlated with NTC and debt ratio (DR). The association between NTC and profitability is statistically significant only at 5 percent level. The results of correlation coefficient show that both PA and PS are negatively correlated with debt to assets ratio and statistically is significant at 1 percent level which implies that use of less debt in capital structure increases corporate profitability in Nepalese manufacturing firms.

\section{Regression Analysis}

In this paper, multiple regression models have been used to explain the relationship between firm's profitability and explanatory variables. Table 2 presents regression results of multivariate models under previous specified equations to explain relationship between efficiency of WCM and their effect on profitability of manufacturing firms in Nepal.

Table 2: Regression Relationship of Firm's Profitability with Explanatory Variables.

\begin{tabular}{|c|c|c|c|c|c|c|c|c|}
\hline Models & Constant & NTC & CR & DR & Adj.R & DW & VIF & F \\
\hline $\begin{array}{c}\text { Model 1: } \\
\text { PA }\end{array}$ & $\begin{array}{c}0.267 \\
\left(3.936^{* *}\right)\end{array}$ & $\begin{array}{c}-0.185 \\
\left(-2.438^{*}\right)\end{array}$ & $\begin{array}{c}0.113 \\
(0.531)\end{array}$ & $\begin{array}{c}-0.106 \\
\left(-5.284^{* *}\right)\end{array}$ & 0.304 & 1.950 & $\begin{array}{c}1.606,1.611, \\
1.852\end{array}$ & $16.735^{* *}$ \\
\hline $\begin{array}{c}\text { Model 2: } \\
\text { PS }\end{array}$ & $\begin{array}{c}0.163 \\
\left(2.685^{*}\right)\end{array}$ & $\begin{array}{c}-0.157 \\
(-2.136)\end{array}$ & $\begin{array}{c}0.085 \\
(1.374)\end{array}$ & $\begin{array}{c}-0.104 \\
\left(-3.584^{* *}\right)\end{array}$ & 0.185 & 1.797 & $\begin{array}{c}1.692,2.575, \\
1.728\end{array}$ & $12.127^{* *}$ \\
\hline
\end{tabular}

Source: SEBON (2005/06-2017/18). 
Note: The figures in the parentheses are $t$-value and asterisk sign indicates that result is significant level. '*' Indicates statistical significance at 5 percent level, and '**' Indicates statistical significance at 1 percent level. Also reported are the Adjusted $R^{2}$, DW statistics, VIF and F-statistics.

The first regression model in Table 2 shows direct relationship between current ratio (CR) and profitability on assets (PA) in manufacturing firms of Nepal. The regression result indicates relationship between total current ratio (CR) and profitability on total assets (PA) of firms seems positive but statistically is insignificant. Result of regression coefficient shows that PA is negatively related with NTC and DR. The relationship between PA and NTC is significant at 5 percent whereas DR has negative and statistically significant impact on PA at 1 percent level. This result is consistent and support with findings of Mayers and Majluf (1984), Rajan and Zingales (1995), Booth, Aivazian, Demirguc-Kunt, and Maksimovic (2001) which implies that DR has strong explanatory power of profit on total assets in Nepalese manufacturing firms. This result suggests that Nepalese manufacturing firms should use less debt to maximize profitability on total assets.

Adjusted coefficient of determinants (Adj. $R^{2}$ ) of model one is 0.314 . This indicates that predicting power of model is 31.4 percent to explain profitability of Nepalese firms by its explanatory variables. The computed values of DW statistic for the model specification one in Table 2 falls between ' $\mathrm{d}_{\mathrm{U}}$ ' and ' $4-\mathrm{d}_{\mathrm{U}}$ '. Thus, there is no evidence to support the problem of autocorrelation and this study is free from problem of autocorrelation. With regards to multicolinearity, VIF of explanatory variables of the model specification of profitability on assets are significantly lower than 10 . Thus, there is no evidence of multicolinearity problems in the regression models applied in this paper. The F-statistics of model one is statistically significant at 1 percent level which implies that the regression model employed in the estimation of profitability on total assets with its explanatory variables is fitness of test of the overall models.

Similarly, regression model two in Table 2 exhibits direct relationship between PS and CR. The regression result indicates relationship between current assets to liabilities (CR) and profitability on sales (PS) seems positive but statistically is insignificant. The result of regression coefficient shows that PS is negatively related with NTC and DR. The relationship of PS with DR is negative and statistically significant at 1 percent level. This result is consistent and supports to the findings of Mayers and Majluf (1984) and Rajan and Zingales (1995) which implies that DR has strong explanatory power of profitability on sales in Nepalese manufacturing firms. This result indicates that use of less debt increases more profitability on sales in Nepalese manufacturing firms. The regression result implies that efficiency in terms of NTC has weak explaining power of profitability on sales of Nepalese manufacturing firms.

The adjusted coefficient of determinants (Adj. $R^{2}$ ) of the model two is 0.185 . This result indicates that predicting power of regression model two is 18.5 percent to explain corporate profitability on sales of manufacturing firms in Nepal by its explanatory variables. This result 
supports the existence of a negative association between capital structure and profitability of firms. The computed values of DW statistics for the model specification of model two fall in between ' $\mathrm{d}_{\mathrm{U}}$ ' and ' $4-\mathrm{d}_{\mathrm{U}}$ '. Thus, there is no evidence to support the problem of autocorrelation and this study is free from problem of autocorrelation. With regards to multicolinearity, VIF of explanatory variables of the model specification of profitability on sales are significantly lower than 10. The result shows that there is no evidence of multicolinearity problems in explanatory variables of the model used in this paper. The F-statistics of model two is statistically significant at 1 percent level which implies that the model applied in estimation of profitability on sales with its explanatory variables is fitness of test of the overall models.

\section{Conclusion}

This paper has been attempted to analyze the relationship between efficiency of working capital management and profitability of manufacturing firms in Nepal using descriptive and causal comparative research design for the study period 2005/06-2017/18. The result of study confirms that profitability of Nepalese manufacturing firms is negatively affected with use of debt in capital structure. This study reveals that both profitability on total assets and profitability on sales of manufacturing firms in Nepal are inversely related with use of debt to assets ratio. The finding of this study supports to the findings of Mayers and Majluf (1984) and Rajan and Zingales (1995), and Booth et al. (2001) who revealed negative relationship between debt and corporate profitability. The result of this study implies that less use of debt (financial leverage) increases firm's profitability in Nepalese manufacturing companies in terms of both profitability on assets and profitability on sales. This study reveals that efficiency of working capital management has no significant role in firm's profitability in Nepalese manufacturing companies. Finally, result of the study concludes that Nepalese manufacturing firms should reduce their use of debt to increase the profitability.

\section{Implications of the Study}

This paper concludes that efficiency of working capital management is one of the dominant dimensions of profitability of manufacturing companies in Nepal. Thus, future study could build on contextualized the effect of efficiency of WCM on firm's profitability. From the policy perspective, greater emphasis is needed on efficiency of WCM to sustain the higher profitability in Nepalese manufacturing firms. Similarly, this study may be useful to the academics in teaching learning activities and research in the field of WCM to increase the profitability by maintaining optimal capital structure. Findings of this paper would be useful for the investors and managers of the firms to get various information of efficiency of WCM to make sound investment decisions on working capital for efficient utilization of various resources for smooth operation of business activities in Nepal. Finally, results of this paper would be useful to policy makers for the formulation and implementation of business and financial policies and strategies. 


\section{References}

Afza, T., \& Nazir, M. S. (2007). Working capital management efficiency of cement sector of Pakistan. Journal of Economics and Behavioral Studies, 2(5), 223-235.

Al-Mwalla, M. (2012). The impact of working capital management policies on firms' profitability and value: The case of Jordan. International Research Journal of Finance and Economics, 85, 147-153.

Beaumont, S. M., \& Begemann, E. (1997). Measuring association between working capital and return on investment. South Africa Journal of Business Management, 28(1), 1-5.

Booth, L., Aivazian, V., Demirguc-Kunt, A., \& Maksimovic, V. (2001). Capital structures in developing countries. Journal of Finance, 56, 87-130.

Deloof, M. (2003). Does working capital management affect profitability of Belgian firms? Journal of Business Finance and Accounting, 30(3), 573-588.

Emery, G. W. (1984). Measuring short-term liquidity. Journal of Cash Management, 4(4) 25-32.

Filbeck, G., \& Krueger, M. T. (2005). An analysis of working capital management results across industries. Mid-American Journal of Business, 20(2), 11-18.

Ganesan, V.(2007). Ananalysis of working capital managementefficiency in telecommunication equipment industry. Rivier Academic Journal, 3(2), 1-10.

Gentry, J., Vaidyanathan, R., \& Lee, H. W. (1990). A weighted cash conversion cycle. Financial Management, 19(1), 90-99.

Gill, A., \& Biger, N. (2013). The impact of corporate governance on working capital management efficiency of American manufacturing firms. Managerial Finance, 39(2), 116-132.

Gitman, L. J. (1994). Estimating corporate liquidity requirements: A simplified approach. The financial Review, 9(1), 79-88.

Grablowsky, B. J. (1984). Financial management of inventory. Journal of Small Business Management, 22(3), 59-65.

Kaur, H. V., \& Singh, S. (2013). Managing working capital efficiency in capital goods sector in India. Global Business Review, 14(2), 343-355.

Kroes, J., \& Manikas, A. (2014). Cash flow management and manufacturing firms' financial performance: A longitudinal perspective. International Journal of Production Economics, $148,37-50$.

Lazaridis, D. I., \& Tryfonidis, D. (2005). The relationship between working capital management and profitability of listed companies in the Athen Stock Exchange. Journal of Financial Management and Analysis, 19(1), 1-12. 
Mayers, S., \& Majluf, N. (1984). Corporate financing and investment decisions where firms Have information that investors do not have. Journal of Finance Economics, 13(2), 187221

Padachi, K. (2006). Trends in working capital management and its impact on firm's performance: An analysis of Mauritian small manufacturing firms. International Review of Business Research Papers, 2(2), 45-58.

Panigrahi, A. K. (2017). Working capital management efficiency of Indian cement industry. NMIMS Journal of Economics and Public Policy, II(January), 8-28.

Paul, P., \& Mitra, P. (2018). Analysis of the effect of working capital management on profitability of the firms: Evidence from Indian steel industry. Asia-Pacific Journal of Management Research and Innovation, 14(1/2), 32-38.

Petersen M. A., \& Rajan, R. G. (1997). Trade credit: Theory and evidence. Review of Financial Studies, 10 (3), 661-691.

Raheman, A., \& Nasr, M. (2007). Working capital management and profitability: Case of Pakistani firms. International Review of Business Research Papers, 3(1), 279-300.

Rajan, R., \& Zingales, L. (1995). What do we know about capital structure - Some evidence from international data? Journal of Finance, 50(5), 1421-1460.

Rauscher, S., \& Wheeler, J. R. C. (2012). The importance of working capital management for hospital profitability: Evidence from bond issuing, not for profit US hospitals. Health Care Management Review, 37(4), 339-346.

Richards, V. D., \& Laughlin, E. J. (1990). A cash conversion cycle approach to liquidity analysis. Financial Management, 9(1), 32-38.

Shin, H., \& Soenen, L. (1998). Efficiency of working capital management and corporate profitability. Financial Practice and Education, 8(2), 37-45.

Smith, K. (1980). Profitability versus liquidity trade-offs in working capital management: Readings on the Management of Working Capital. St. Paul: West Publishing Company.

Smith, K. (1973). State of the art of working capital management. Financial Management, Autumn, 2(3), 50-55.

Teruel, P. J. G., \& Solano, P. M. (2007). Effects of working capital management on SME profitability. International Journal of Managerial Finance, 3(2), 164-177.

Van Horne, J. C. (1977). A risk-return analysis of a firm's working capital position. Eng. Econ., 2(1), 71-88. 
Vartak, P., \& Hotchandani, V. (2019). Working capital management and firm performance: Evidence from Indian listed firms. International Journal of Management, Technology and Engineering, 9(4), 914-925.

Wasiuzzaman, S. (2015). Working capital and firm value in an emerging market. International Journal of Managerial Finance, 11(1), 60-79. 